\title{
Neurolinguistic Programming and Regular Verbs Past Tense Pronunciation Teaching
}

\author{
David R. Caballero ${ }^{1} \&$ Nayibe Rosado $^{1}$ \\ ${ }^{1}$ Instituto de Idiomas, Universidad del Norte, Colombia \\ Correspondence: Nayibe Rosado, Instituto de Idiomas, Universidad del Norte, Puerto Colombia, Atlántico, Km 5 \\ Via Puerto Colombia, Colombia. Tel: 57-300-814-7185. E-mail: nrosado@uninorte.edu.co
}

Received: August 3, 2018 Accepted: October 6, 2018 Online Published: October 9, 2018

doi: 10.5539/elt.v11n11p1 URL: http://doi.org/10.5539/elt.v11n11p1

\begin{abstract}
A troublesome pronunciation issue for Spanish EFL learners is the past -ed ending of regular verbs. Neuro linguistic Programming (NLP) is a perspective integrating neurology, language and programming which are key for processing information and for responding to learners' styles with the potential to help EFL teachers address this pronunciation issue. This paper reports a study conducted in two subsequent terms with 43 students at a university language institute: two groups taught using standard pronunciation techniques and two using NLP techniques preceded by oral tasks in which they were encouraged to pronounce regular verbs in the past. Data collected included students self-recorded pronunciation tasks, a survey to elicit students' motivation and satisfaction and a teacher's log with insights about students' attitude and response to the strategy. Analysis of the data showed that after the first implementation, the NLP group improved their pronunciation a 30\%, the standard one improved a $10 \%$. During the second implementation, the NLP group showed an improvement of $23.7 \%$ pronunciation accuracy in task 1 and a $24.6 \%$ in task two compared to the standard group. The findings suggest that teacher's use of NLP techniques into their classroom instruction has a positive impact on students' pronunciation of the past ending of regular verbs.
\end{abstract}

Keywords: regular verbs, pronunciation difficulties, NLP, English regular verbs ending in -ed

\section{Introduction}

\subsection{The Problem}

This study resulted from an investigation related to the techniques used for the treatment of oral errors in tasks used by native and non-native English-speaking teachers in a Colombian language institution (Caballero, 2012). In the study, it was found that teachers' instructional pronunciation repertoire was not varied failing to reach an ample number of students with diverse learning styles and preferences. This is echoed by many authors in the field (Añorga \& Benander, 2015; Buss, 2012; Celce-Murcia, Brinton, \& Goodwin, 2010; Morin, 2007; Sifakis \& Sougari, 2005; Wei; 2006), who report that English pronunciation has been sidelined in EFL/ESL teacher education programs and in classrooms throughout the world leaving teachers on their own in relation to pedagogically informed pronunciation strategies or techniques to use in the classroom. Foote, Holtby, and Derwing (2011) stress that language teachers do not actually receive adequate training in the specific area of pronunciation teaching as confirmed by other researchers (Henderson et al., 2015; Saito, 2012).

\subsection{Importance of Studying This Problem}

The current investigation contributes an instructional strategy for the teaching of a troublesome pronunciation issue for Spanish EFL learners: the past -ed ending of regular verbs. The review of literature in the Colombian context shows the scarcity of scholarship about the teaching/learning of pronunciation including the pronunciation of regular verbs in the past. Therefore, the study's contribution is two-folded: on the one hand, an instructional strategy that could be helpful to teachers in their classrooms; and on the other hand, a classroom-based research to enrich the field (Fraser, 2000). The instructional strategy integrates Neuro-Linguistic Programming (NLP hereafter) into the EFL teaching repertoire. NLP is a multimodal instructional strategy (Hazan \& Li, 2008) and as such has the potential of facilitating students' learning of the pronunciation of the past tense of regular verbs. Darn (2005) explains NLP "is about the way the brain works, and how the brain can be trained for the purpose of betterment" (para. 2). NLP is very much related to left / right 
brain functions, visual / auditory / kinesthetic learning styles and multiple intelligences so it addresses learners more holistically and effectively. This study sets out to explore how the use of NLP techniques may have an incidence in the improvement of the pronunciation of /ed/ regular verbs of Colombian EFL speakers.

\section{Relevant Concepts and Research}

\subsection{Teaching of Pronunciation}

More than six decades ago, approaches to language teaching such as the grammar translation-method did not consider the teaching of pronunciation as an important part of the curriculum, and thus, "pronunciation was almost irrelevant and therefore, seldom taught" (Pourhossein, 2011a, p. 2). As time has passed, pronunciation has been given more importance and incorporated into EFL curricula. Nowadays, as reported by researchers, current pronunciation instructional practices seem to range from intuitive-imitative approaches to analytic-linguistic approaches (Celce-Murcia, Brinton, Goodwin, \& Griner, 2010; Burgess \& Spencer, 2000, Foote et al., 2011).

Depending on how items within a curriculum are selected, organized and taught, it is possible to distinguish two broad approaches to teaching: bottom-up or top-down. In teaching pronunciation, lessons beginning with the articulation of individual vowels and consonants and working up towards intonation use a bottom-up approach. Lessons that include patterns of intonation and give a sharper focus to separate sounds use a top-down approach (Dalton \& Seidlhofer, 1995).

In these two approaches the emphasis is placed in a continuum from the phonetic, phonological, psychological, and physical features, to the segmental and suprasegmental ones (Dalton \& Seidlhofer, 1995). However, these approaches are language and teaching oriented, not necessarily learning or learner oriented. The learning process has not been given the needed prominence; the learners' thought processes or metacognition have not been fully considered either (Pennington, 2008).

Dickerson (1994) highlighted the importance of learner empowerment in pronunciation and asserted that it was crucial to provide students with predictive skills they could use to anticipate how to pronounce new words and sentences as it is done in other areas of ESL instruction (i.e. grammar rules and spelling). However, over-generalization may be an issue in the way learners process information as it could lead to misuse of rules and poorly formed hypotheses. Besides, both teachers and students may find prediction of rule patterns overwhelming, confusing and difficult to remember.

EFL teachers' instructional decisions are central to helping students improve pronunciation (Saito, 2012). EFL Teachers should be aware that explicit, systematic and pedagogically informed pronunciation instructional techniques, "even over a short period of time," could help students "to deal with the perception and/or production of these verbs" (Delatorre \& Baptista, 2014, p. 60) and reduce over-generalization.

In Colombia, the literature related to the teaching/learning of pronunciation is scant, and this includes the teaching of pronunciation of regular verbs in the past. Gomez and Peláez (2012) explored pronunciation teaching/learning in a ninth grade in a public school in Pereira, Colombia, confirming that pronunciation was not tackled in the EFL classroom and when it was done, it was ineffective; It was not tested, and the students did not appear to know what pronunciation entails. Use of Spanish to teach English minimized the opportunities for upgrading this sub-skill (p. I).

A study by Muñoz, Aristizabal et al, (2002) in Medellin, Colombia about oral language, showed that teachers lack expertise in the teaching and assessment of pronunciation, and many of the teachers' techniques are not communicative. It concluded that teachers' use of traditional methods in oral production teaching is not helping students in their communicative competence. In a similar line, Gutiérrez (2005) asserts that in Colombian public schools, the speaking skills are not developed because of factors such as the overuse of grammatical approaches to teaching which lower students' motivation in the learning process. Soto (2009) calls for the use of the phonetic symbols to improve pronunciation learning. A study by Londoño-Diaz (2014) incorporated certain strategies that allow language learners or pre-service teachers to monitor their L2 pronunciation learning as well as the use of collaborative study groups (CSG) as an effective strategy for the construction of knowledge. Results confirmed that the inclusion of collaborative learning tasks encourages students to express their opinions, to discuss and negotiate ideas with others and was effective for less competent learners. Besides, phonological awareness was enhanced and monitoring strategies were adopted throughout the application of the intervention. Pedagogical abilities were strengthened in the process along with other language skills promoted through the experience ( $\mathrm{p}$. ii). More recently, a study by Calderon, Rios and Toro (2016) which aimed to report on how the pronunciation component is incorporated by pre-service English teachers in two public schools located in Pereira, Colombia, found pre-service teachers' pronunciation teaching was limited to only two main strategies: immediate and 
delayed feedback procedures; and also found overall negative perceptions concerning pronunciation teaching.

In Colombia, as it is in other contexts, learners of English have major difficulties with English pronunciation even after years of learning the language affecting considerably their success in communication (Hinofotis \& Baily, 1980, pp. 124-125). Teachers' lack of adequate pronunciation instructional strategies may be a cause. As noted, the few studies found in Colombia highlight the need of conducting research in this field.

\subsection{Pronunciation of Past Tense of Regular Verbs}

One of the issues related to pronunciation is transference. Avery and Ehrlich (as cited in Pourhossein, 2011b), explain that "the sound pattern of the learner's first language is transferred into the second language and is likely to cause foreign accents" (p. 78). Pronunciation studies in romance languages such as Portuguese, place the past of regular verbs in a prominent place (Alves, 2004; Baptista, 2001, 2002; Delatorre, 2006a; Fernandes, 2009; Gomes, 2009, 2010; Pereira, 1994). Delatorre and Baptista (2012) and Pereira (1994) found there is considerable interference from the first language (L1) in the production of clusters formed by the addition of -ed in Brazilian EFL learners. Prator and Robinet (1985) quoted by Delatorre and Baptista (2012, p. 59) list (a) the addition of a syllable, as in robbed /robid/; (b) the pronunciation of the -ed as /t/ after approximants and vowels, as in dared /daert/; and (c) the omission of the -ed ending, as in answered /anser/ as frequent pronunciation errors made by English non-native speakers. Avery and Ehrlich, (2006) assert that one of the most common problems to all dialects of Spanish is the pronunciation of the past tense of regular verbs (-ed). Roothooft (2012) corroborates the same idea by saying that

In Spanish, there are no words ending in final $/ \mathrm{t} /$ and final $/ \mathrm{d} / \mathrm{is}$ either realized as a voiced or voiceless fricative, or simply not pronounced. Also, some consonant clusters might cause problems for Spanish speakers and speakers with other first languages, as Ellis (2006) points out: "The /t/ or /d/ allomorph in kissed and raised creates a phonologically challenging consonant cluster that invites reduction, especially when the next word begins with yet another consonant (2013, p.224).

Bardovi-Harlig and Reynolds (1995) (quoted by Takashima \& Ellis, 1999) have discussed difficulties in the order of acquisition of the /ed/ depending on the class of event:

Learners find it easier to mark certain classes of verbs for past tense than others. For example, they mark verbs referring to events (e.g. 'arrive') first, then activity verbs (e.g. 'sleep') and finally state verbs (e.g. 'want'). It is clear from the available research that the acquisition of past tense forms is a slow and complex process (176-177).

As stated by Delatorre and Baptista, (2014 and confirmed by other researchers in the field (Alves, 2004; Mariano, 2009; Silveira \& Alves, 2006) "only a few studies have investigated the effect of instruction on learners' production and/or perception of regular verbs ending in -ed (p. 60). Delatorre and Baptista, (2014) followed the progress of an undergraduate female Brazilian EFL learner for three semesters to determine whether her improvement was fairly uniform or varied after instruction on the pronunciation of regular verbs in the past. With the study, they corroborated the results of previous studies in the sense that the frequent error of vowel epenthesis was drastically reduced with almost two years of pronunciation instruction. They report that preceding voiceless contexts except $/ t /$ induced higher rates of vowel epenthesis than voiced contexts except $/ \mathrm{d} /,[\ldots]$ and that there was much less improvement in the voiceless contexts; verbs in which the -ed was preceded by $/ \mathrm{t} /$ or $/ \mathrm{t} /$ were usually accurately produced, not surprising since the accurate pronunciation does require a vowel, and thus did not improve with instruction (p. 59).

\subsection{Neuro-Linguistic Programming (NLP)}

NLP is common in education and it is already in use in many classrooms. When "teachers [ ] incorporate elements of suggestopedia, community language learning, music, drama and body language into their lessons are already drawing on NLP as it stood twenty years ago" (Darn, 2005, para. 1). Authors like Sumrall (2003) state: "Neuro-Linguistic Programming (NLP) and related applications can be effectively applied to improving the educational outcomes for students, teachers, administrators, and the community" (para. 1). She also asserts that "The overall goal of NLP applied to education is to provide a basic framework that is aligned with the empirical experience of learning and training situations for the purpose of improving the effectiveness and speed with which goal-oriented learning can take place" (para. 4).

Much of the compatibility of education and NLP has to do with its basis: how information is processed, arriving via the senses in "six modalities", which are the ways that different individuals perceive the outside. The modalities are: visual remembered, visual constructed, auditory remembered, auditory remembered, auditory digital, kinesthetic, known as "VAK". They address the different types of learners: visual, auditory and 
kinesthetic, thus catering for different learning styles in the classroom (Darn, 2005, para. 6).

Darn also explains that deletion, distortion and generalization are important for the modification of perception and are in the center of understanding of how information is processed. Deletion happens when there is too much information for the learner to handle so they delete or omit to make input manageable. Learners will distort information into forms which are understandable and learnable. It could be both negative, in that it produces errors and misunderstandings, and positive in that it contributes to learnability and motivation. Generalization is one of the ways in which people learn, by taking the information and drawing broad conclusions from there. At its worst, over-generalization occurs, causing misuse of rules and poorly formed hypotheses (Darn, 2005, para. 7).

These three elements of modification in perception could shed light on why some learners make mistakes in pronunciation and repeat them with regularity. Some people, for example, write some words making the same spelling mistake over and over again. The problem in this case is that they remember the incorrect spelling (Dilts \& Epstein, 1997). Another example is those people who have studied a foreign language for years or have lived abroad, in the country where the language is spoken, and still have pronunciation problems or a very strong native accent. This could be attributed to distortion or generalization.

Dilts and Epstein's (1995) quoted by Sumrall (2003, para. 5) state that "the basic applications of NLP to education revolve around the principles of dynamic learning" which capitalize learning through experience. Dynamic learning involves learning by doing, exploring different methods of thinking, and acknowledges that the relationships between people are a key factor in learning. Here we notice the humanistic roots of the NLP approach. "Dynamic learning tools emphasize the skills of cooperative learning, co-coaching, and mentoring. Dynamic learning methods use the modeling principles and tools of NLP to release natural learning capabilities through awareness, exploration and discovery" (James, 1996 quoted by Sumrall, 2003, para. 5). This has been confirmed by Bashir and Ghanni (2012) in a study that used NLP associated to communication in the classroom and that have put the learner in a relevant position in the teaching-learning process and "teacher-learner relationship as a constant and consistent feedback oriented interactive association. It is not a one-way process, but meaning is conveyed and constructed through shared and mutual understanding (p. 219).

Dilts and Epstein (1997) list some outcomes of the application of NLP to education, some applicable to the Spanish speakers' pronunciation instruction and learning: 1) enhancing memory, 2) developing optimal learning states and strategies, 3) dealing with resistances to learning,4) identifying and reframing limiting beliefs relating to learning, 4) exploring interactive learning processes (para.5).

\subsection{Anchoring: A Powerful NLP Technique for Pronunciation}

Anchoring is a way to record states for later retrieval. It is a simple but effective technique to have access to emotions, resources or internal states of positive nature, anytime we need them. Anchors connect sensory impacts, something that arrives at the visual, auditory and kinesthetic channels with experiences and memories (Carrión, 2007). This author explain that anchors establish an immediate visual, auditory or kinesthetic relationship with the state experienced at that moment and then, later, we only reproduce the stimulus and the state will come back (Carrión, 2007). Students could reproduce the stimulus themselves and, in that way, self-edit or repair their pronunciation.

Anchoring is a powerful technique teacher could use first, to avoid the distortion of information that could lead to mistakes, and second, to delete information that has become a mistake in terms of pronunciation. Anchoring can be used to teach stress. Every time the pronunciation of a word whose stress is typically misplaced is taught, emphasis can be made on the stress by increasing the volume of the voice in the specific syllable that is stressed. Kinesthetic learners can be addressed by making movements with the body and exaggerating the stress. Music is also part of anchoring since it ".. helps us learn because it will establish a positive learning state, ...facilitate a multi-sensory learning experience, $\ldots$ and improve memory" (Brewer, 1995, para. 7). Thus, these anchoring NLP techniques can be really useful to support the pronunciation of the past of regular verbs accompanying standard techniques. The former address the needs of different kinds of learners (kinesthetic, visual and auditory).

\section{Methodology}

This study was implemented in two subsequent terms over a year at a university language institute in Barranquilla, Colombia with intermediate (B1) level students. Students were organized into either a NLP group or a standard group. The intervention was developed in two iterations or implementations. The first implementation aimed to help students in the recalling of the correct pronunciation of regular verbs in the past by using NLP techniques. Learners read and recorded a text containing regular verbs before and after NLP 
instruction (See Appendices A and B). A question deriving from the first implementation was if NLP could help students pronounce the verbs correctly in a more natural and spontaneous task. Thus, for the second implementation, a spontaneous task was used to see the effect of NLP in such a task (See Appendix C).

To learn about the impact of the strategy on learners' motivation and satisfaction, a survey was applied to the NLP group (See Appendix D). Also, the teacher kept a log to record the insights gained in terms of students' attitude and responses during the classroom implementation of the strategy.

\subsection{Participants}

Participants were students from different majors taking their level 6 English required course at the university language institute. Students enter this course in B1 initial and are expected to exit with B1.1 (According to CEF) Students' ages range from 18 to 22 years old. All students from two B1 classes participated of regular English classes and received either standard instruction in regular verbs /ed/, past tense pronunciation or NLP instruction; we only reported data from students who consented to share their data: 12 students in the first implementation: 5 in the standard group or the group that did not use NLP and 7 in the NLP group. 31 students participated in the second implementation: 18 in the standard group and 13 in the NLP group.

\subsection{Intervention}

\subsubsection{Implementation One}

The aim of the first implementation was to compare students' progress in the pronunciation of regular verbs in the past. Students from the NLP and the standard groups were asked to record themselves reading a text containing 10 regular verbs in the past prior to instruction.

\subsubsection{The Standard Group}

Students in the group received traditional pronunciation instruction in which the teacher used techniques such as explicit explanation of pronunciation rules followed by regular verb pronunciation ending drilling. After instruction, students were asked to read and record the same text again. Five students sent their post-instruction recording for analysis.

\subsubsection{The NLP Group}

Students in this group received explicit instruction using only NLP anchoring pronunciation techniques. Students were shown a table with three columns with the three different pronunciations of regular verbs in the past and three names of people as headings to represent the final sound that must be pronounced in each one of the groups of verbs (Bert for /t/, Fred for /d/, and David for /Id/) (See Appendix E). For visual learners, the verbs were separated in syllables, so that they could identify the number of syllables they were supposed to pronounce. Some of the verbs were associated with things that could be memorable to students. For example, the verb like in the past is pronounced /'laikt/. Students were told the pronunciation is exactly the same for the word "light" and they were shown a light on the ceiling and a picture on the board. In the case of the verb watch, they were told to think about a "guacharaca", which is a musical instrument used to play Vallenato music (Typical music from Colombia). They were told the pronunciation of that verb sounds like the sound produced by that instrument, so the sound was produced and besides, the playing of a guacharaca was mimicked, this to help kinesthetic learners. In the end, both auditory and visual learners could create anchors for the correct pronunciation of those two verbs.

Afterwards, the class was divided into three groups. Students were told the activity was a pronunciation musical competition. Each group was in charge of pronouncing one column. They were to choose a specific sound, such as clapping, snapping of fingers, etc. The group was asked to pronounce the list of verbs reproducing the sound and keeping rhythm as they pronounced each one of the syllables in each word. They had some time to practice to fine tune the beat. After that, each one of the groups "performed" their list of verbs displaying their musical creativity. The following class, students were asked to read and record again the text they have read prior to the intervention in order to analyze their progress. Seven students sent their post-instruction recording for analysis.

\subsubsection{Implementation Two}

In the second implementation there were 18 students in the standard group and 13 students in the NLP one. As in the first implementation, both groups were taught the past ending /ed/ of regular verbs: the standard group with traditional pronunciation teaching techniques, and the other group, with NLP techniques (see NLP class description above). Unlike implementation one, this time students were not asked to do a pre-instruction recording. Instead, students were asked to perform two tasks post- instruction: 1) a recorded reading of a text containing 8 regular verbs in the past; 2) a spontaneous recorded answer to a question which elicited the use of 
regular verbs in the past, a list of studied verbs was given to them along with the question (See Appendices A and B).

\subsection{Procedures for Data Collection and Analysis}

In both implementations the recordings were analyzed auditorily by the researchers to determine if the target verbs past tense /ed/ pronunciation was accurate. An excel table was used to keep record of accurate and inaccurate pronunciation: a number one was given to accurate and zero for inaccurate. Since this is a case study, no statistical tests were run and only percentages were calculated, thus demonstrating only tendencies. The percentages of verbs produced in each of these categories were calculated from the total number of verbs in -ed produced during each of the recordings and from the total number of productions for each allomorph.

\section{Results and Discussion}

\subsection{Results From Implementation One}

Figure one shows the progress made by the two groups participating in implementation one (IMPL1 hereafter). As shown, the standard group's entry level was higher showing an improvement of $10 \%$ in the exit level. However, the NLP made more progress: the difference between their entry level and their exit level was $30 \%$.

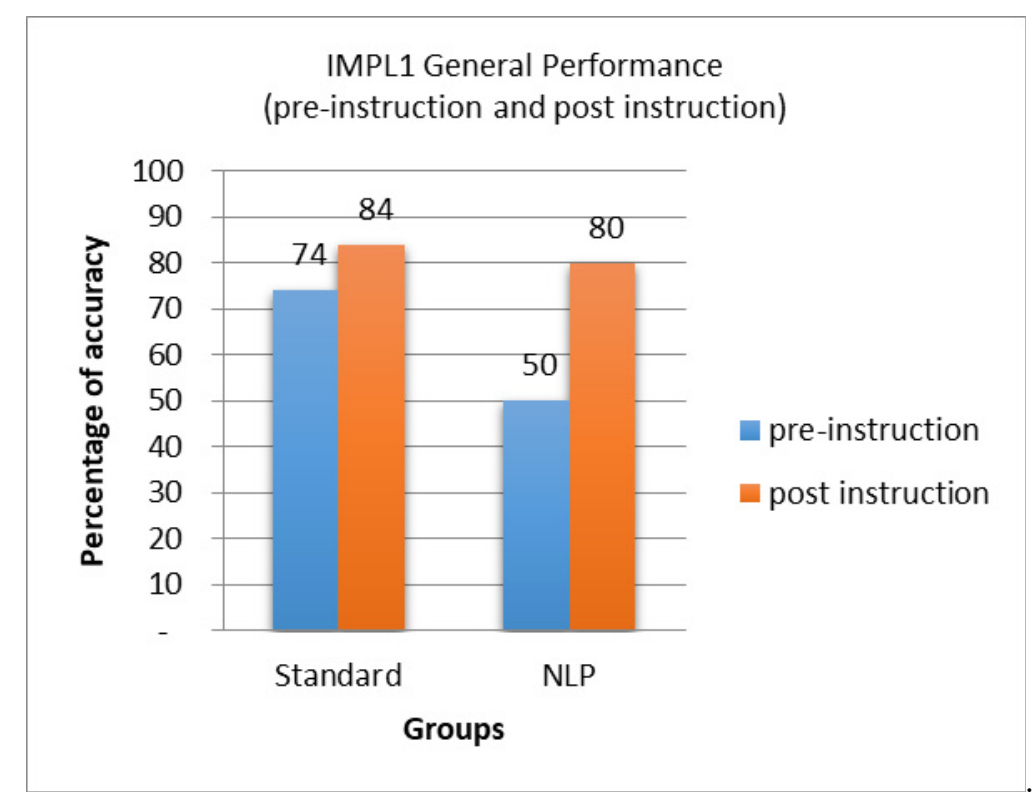

Figure 1. Standard and NLP group progress: pre and post instruction

Figure two provides a more detailed look of the results: the percentage of correct pronunciation per verb in both groups. The pre-instruction results showed the standard group pronounced more verbs better. However, in the post-instruction results, the number of students in the NLP group who pronounced more verbs correctly was higher. 


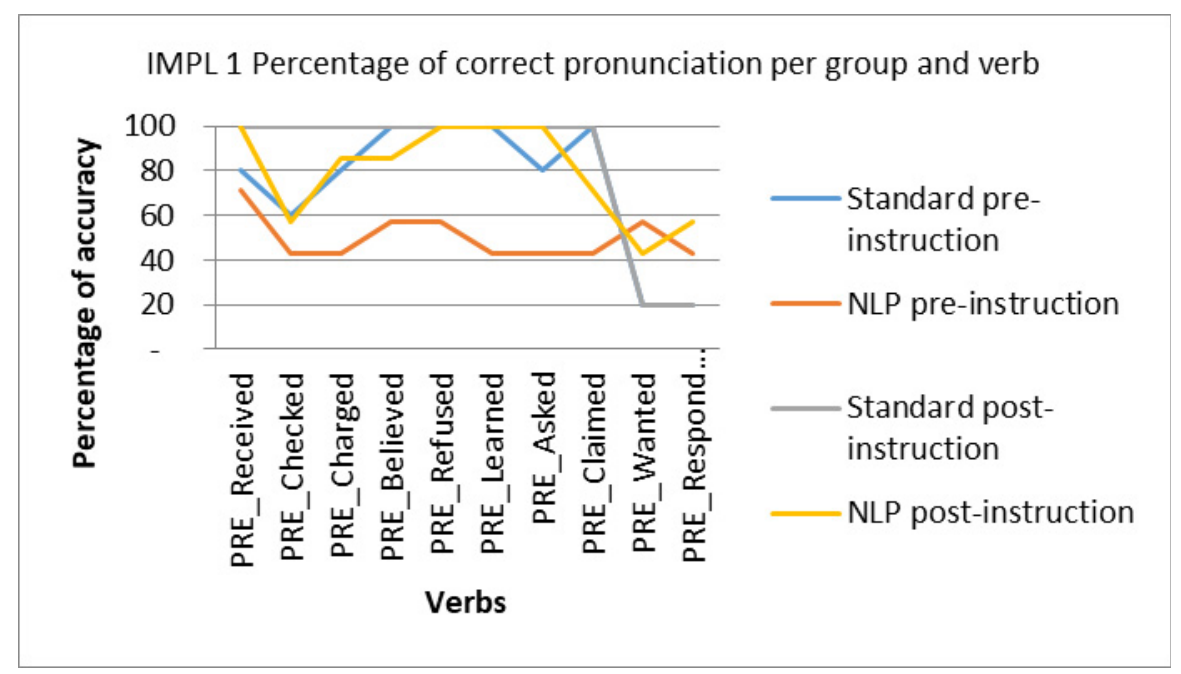

Figure 2. Percentage of correct pronunciation of verbs per group and verb

\subsection{Results From Implementation Two}

\subsubsection{Results From Activity One: Reading the List of Verbs}

The blue bar in figure three represents the NLP group, and the green one, the standard group. As it is evident, the NLP group got a higher percentage of accuracy compared to the standard group. As shown in the grey bar the difference between the two was of a $23.7 \%$. Results from implementation one are confirmed.

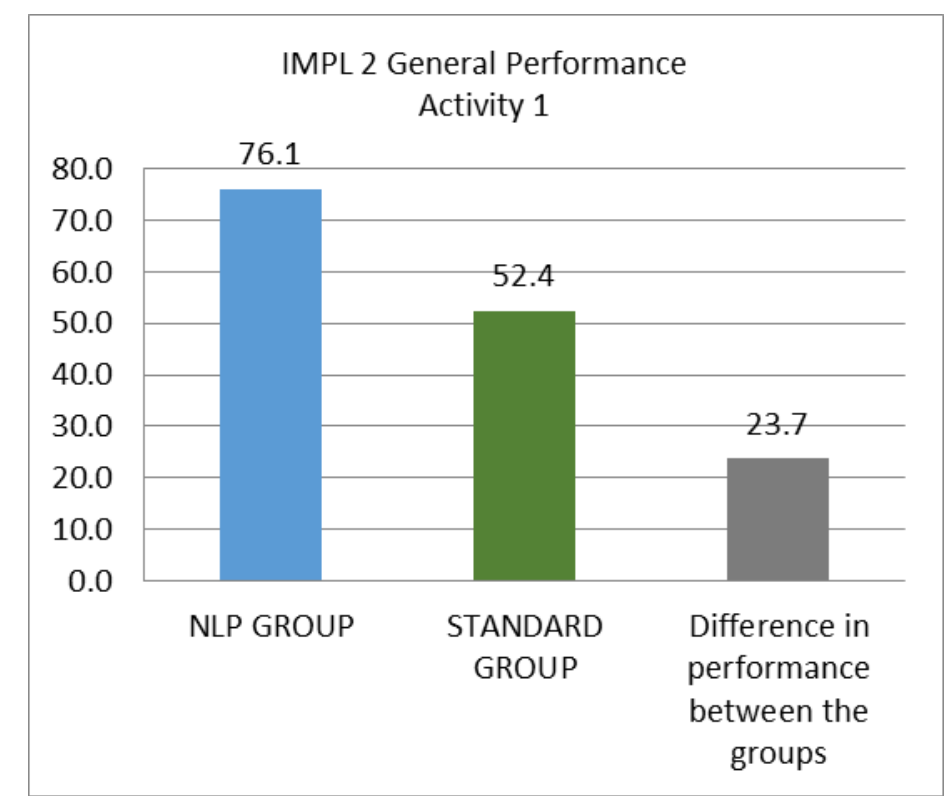

Figure 3. Implementation 2 general performance activity 1

4.2.2 Detailed analysis of results in activity one: standard group

In another layer of analysis, the pronunciation of the verbs was separated according to the rules of verbs ending in $/ \mathrm{t} /$ and $/ \mathrm{d} /$.

Results of verbs ending in / $t$ /, reveal that in general, $55.5 \%$ of them pronounced the group of verbs accurately. A $67 \%$ pronounced the verb collapsed correctly; and a $44 \%$ pronounced worked correctly. 
Table 1. / t/ group, standard

\begin{tabular}{lll}
\hline$/ \mathbf{t} /$ & CORRECT & INCORRECT \\
\hline Collapsed & $67 \%$ & $33 \%$ \\
worked & $44 \%$ & $56 \%$ \\
\hline
\end{tabular}

The analysis of the verbs ending in /d/ shows that the accuracy in the pronunciation of this group of verbs was higher than in the /t/ group. A $67 \%$ of the students pronounced the verbs mangled and believed correctly; a $61 \%$ changed; a 56\% discovered; a 50\% scared and learned and a $17 \%$ pronounced soared in a correct way.

Table 2. / d/ group, standard

\begin{tabular}{lll}
\hline$/ \mathbf{d} /$ & CORRECT & INCORRECT \\
\hline Mangled & $67 \%$ & $33 \%$ \\
Believed & $67 \%$ & $33 \%$ \\
Changed & $61 \%$ & $39 \%$ \\
Discovered & $56 \%$ & $44 \%$ \\
Scared & $50 \%$ & $50 \%$ \\
Learned & $50 \%$ & $50 \%$ \\
Soared & $17 \%$ & $83 \%$ \\
\hline
\end{tabular}

\subsubsection{Detailed Analysis of Results in Activity One: NLP Group}

On the whole, the NLP group performed accurately in an average of $76.1 \%$.

$/ \mathrm{t} /$

A $69 \%$ of the NLP group pronounced correctly this group of verbs. A $85 \%$ pronounced collapsed correctly while $54 \%$ pronounced worked correctly.

Table 3. /t /group, NLP

\begin{tabular}{lll}
\hline$/ \mathbf{t} /$ & CORRECT & INCORRECT \\
\hline Collapsed & $85 \%$ & $15 \%$ \\
Worked & $54 \%$ & $46 \%$ \\
\hline
\end{tabular}

A $92 \%$ of the students pronounced believed correctly; this is the highest percentage of accuracy for any of the verbs in the study; a 85\% pronounced mangled and discovered well; a 77\% changed, scared and learned; and a $54 \%$ soared.

Table 4. /d/ group, NLP

\begin{tabular}{lll}
\hline$/ \mathbf{d} /$ & CORRECT & INCORRECT \\
\hline Believed & $92 \%$ & $8 \%$ \\
Mangled & $85 \%$ & $15 \%$ \\
Discovered & $85 \%$ & $15 \%$ \\
Changed & $77 \%$ & $23 \%$ \\
Scared & $77 \%$ & $23 \%$ \\
Learned & $77 \%$ & $23 \%$ \\
Soared & $54 \%$ & $46 \%$ \\
\hline
\end{tabular}




\subsubsection{Results From Activity Two: Response to a Question}

This one was a more natural and spontaneous task and as it can be noticed, the percentage of accuracy of the pronunciation of regular past tenses decreased in both groups. However, if we take a look at the percentage of the difference between the two, pronunciation accuracy remained higher in the NLP group. As shown in the green bar the difference between the two was of a $24.6 \%$.

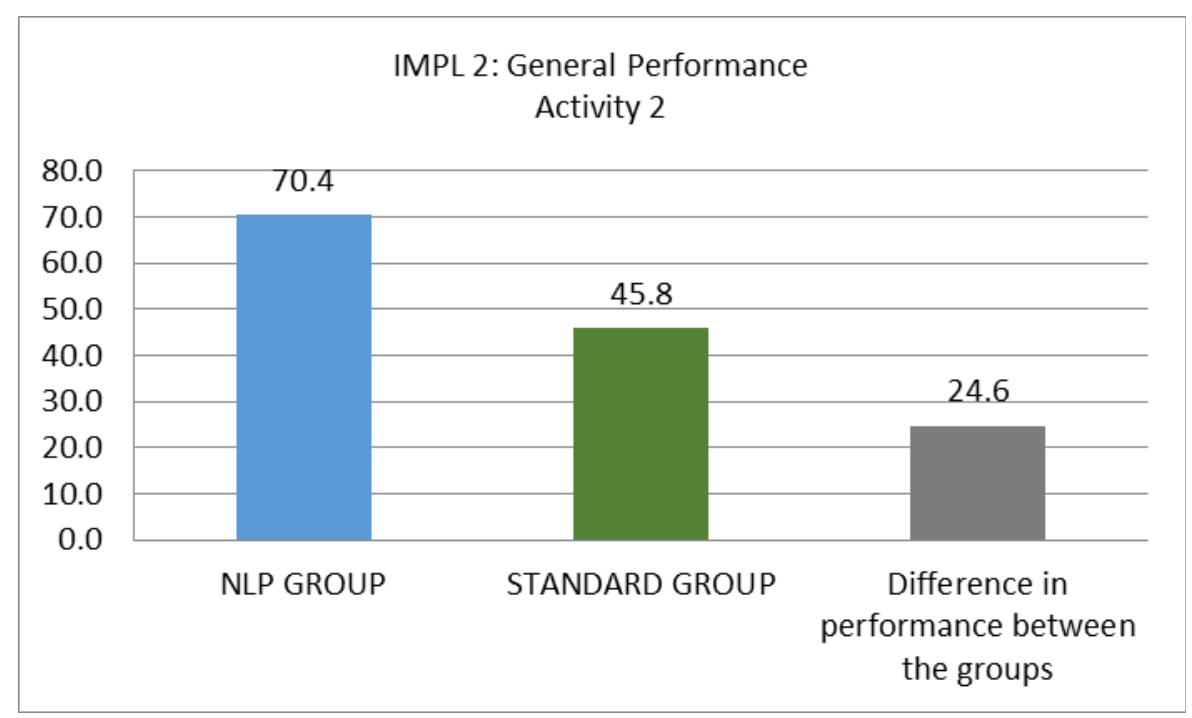

Figure 4. Implementation 2 general performance activity 2

\subsubsection{Detailed Analysis of Results in Activity Two: Standard Group}

Overall, students pronounced 5 verbs out of the 11 with an accuracy average for those verbs of a $44,44 \%$.

/t/

$100 \%$ pronounced the verb helped correctly, followed by faced with a $67 \%$ of accuracy. Convinced and realized with a $50 \%$ of accuracy; next was collapsed with a $40 \%$; worked with a $29 \%$; and finally, liked with a $0 \%$ of accuracy.

Table 5. / t/ group, standard

\begin{tabular}{lll}
\hline$/ \mathbf{t} /$ & CORRECT & INCORRECT \\
\hline Helped & $100 \%$ & $0 \%$ \\
Faced & $67 \%$ & $33 \%$ \\
Realized & $50 \%$ & $50 \%$ \\
Convinced & $50 \%$ & $50 \%$ \\
Collapsed & $40 \%$ & $60 \%$ \\
Worked & $29 \%$ & $71 \%$ \\
Liked & $0 \%$ & $100 \%$ \\
\hline
\end{tabular}

A $100 \%$ pronounced studied, called, and believed in a correct way; a 50\% pronounced discovered and inspired correctly; a $43 \%$ learned, and a $0 \%$ of accuracy for determined and dreamed. 
Table 6. / d/ group, standard

\begin{tabular}{lll}
\hline /d $/$ & CORRECT & INCORRECT \\
\hline Studied & $100 \%$ & $0 \%$ \\
Called & $100 \%$ & $0 \%$ \\
Believed & $100 \%$ & $0 \%$ \\
Discovered & $50 \%$ & $50 \%$ \\
Inspired & $50 \%$ & $50 \%$ \\
Learned & $43 \%$ & $57 \%$ \\
Determined & $0 \%$ & $100 \%$ \\
Dreamed & $0 \%$ & $100 \%$ \\
\hline
\end{tabular}

A $100 \%$ pronounced the verbs wanted, separated, adopted, accepted complicated, permitted, accurately and 50\% pronounced affected well; $0 \%$ pronounced needed, decided, committed, and supported inaccurately.

Table 7. /id/ group, standard

\begin{tabular}{lll}
\hline /id/ & CORRECT & INCORRECT \\
\hline Wanted & $100 \%$ & $0 \%$ \\
Separated & $100 \%$ & $0 \%$ \\
Adopted & $100 \%$ & $0 \%$ \\
Accepted & $100 \%$ & $0 \%$ \\
Complicated & $100 \%$ & $0 \%$ \\
Permitted & $100 \%$ & $0 \%$ \\
Affected & $50 \%$ & $50 \%$ \\
Decided & $0 \%$ & $100 \%$ \\
Needed & $0 \%$ & $100 \%$ \\
Committed & $0 \%$ & $100 \%$ \\
Supported & $0 \%$ & $100 \%$ \\
\hline
\end{tabular}

\subsubsection{Detailed Analysis of Results in Activity Two: NLP Group}

On the whole, a $73 \%$ of students in this group performed well in the pronunciation of the past tenses.

/t/

A $100 \%$ of them pronounced caused, practiced, realized, kicked and teased correctly; a 83\%, convinced; a $75 \%$, collapsed; a 43\%, worked.

Table 8./t/ group, NLP

\begin{tabular}{lll}
\hline$/ \mathbf{t} /$ & CORRECT & INCORRECT \\
\hline Caused & $100 \%$ & $0 \%$ \\
Practiced & $100 \%$ & $0 \%$ \\
Realized & $100 \%$ & $0 \%$ \\
Kicked & $100 \%$ & $0 \%$ \\
Teased & $100 \%$ & $0 \%$ \\
Convinced & $83 \%$ & $17 \%$ \\
\hline
\end{tabular}




\begin{tabular}{lll}
\hline Collapsed & $75 \%$ & $25 \%$ \\
Worked & $43 \%$ & $57 \%$ \\
\hline
\end{tabular}

In this group, a $93 \%$ pronounced the verbs correctly.

A $100 \%$ pronounced fractured, learned, studied, inspired, traveled, called, showed, believed, enjoyed and disciplined accurately; a $60 \%$, discovered; a $50 \%$, dreamed, and a $0 \%$ of accuracy for scared.

Table 9. /d/ group, NLP

\begin{tabular}{lll}
\hline$/ \mathbf{d} /$ & CORRECT & INCORRECT \\
\hline Fractured & $100 \%$ & $0 \%$ \\
Learned & $100 \%$ & $0 \%$ \\
Studied & $100 \%$ & $0 \%$ \\
Inspired & $100 \%$ & $0 \%$ \\
Traveled & $100 \%$ & $0 \%$ \\
Called & $100 \%$ & $0 \%$ \\
Showed & $100 \%$ & $0 \%$ \\
Believed & $100 \%$ & $0 \%$ \\
Enjoyed & $100 \%$ & $0 \%$ \\
Disciplined & $100 \%$ & $0 \%$ \\
Discovered & $60 \%$ & $40 \%$ \\
Dreamed & $50 \%$ & $50 \%$ \\
Scared & $0 \%$ & $100 \%$ \\
\hline
\end{tabular}

A $100 \%$ pronounced accurately the verbs started and needed, and with a $\% \%$ of accuracy were wanted, united, decided.

Table 10. /id/ group, NLP

\begin{tabular}{lll}
\hline /id/ & CORRECT & INCORRECT \\
\hline Started & $100 \%$ & $0 \%$ \\
Needed & $100 \%$ & $0 \%$ \\
Wanted & $0 \%$ & $100 \%$ \\
United & $0 \%$ & $100 \%$ \\
Decided & $0 \%$ & $100 \%$ \\
\hline
\end{tabular}

\subsection{Results From Students'Survey and Teacher's Log}

Students were asked to rate their satisfaction with the use of the NLP strategy in class. Their answers were positive with most students' responses in 4 and 5 , the highest level. 


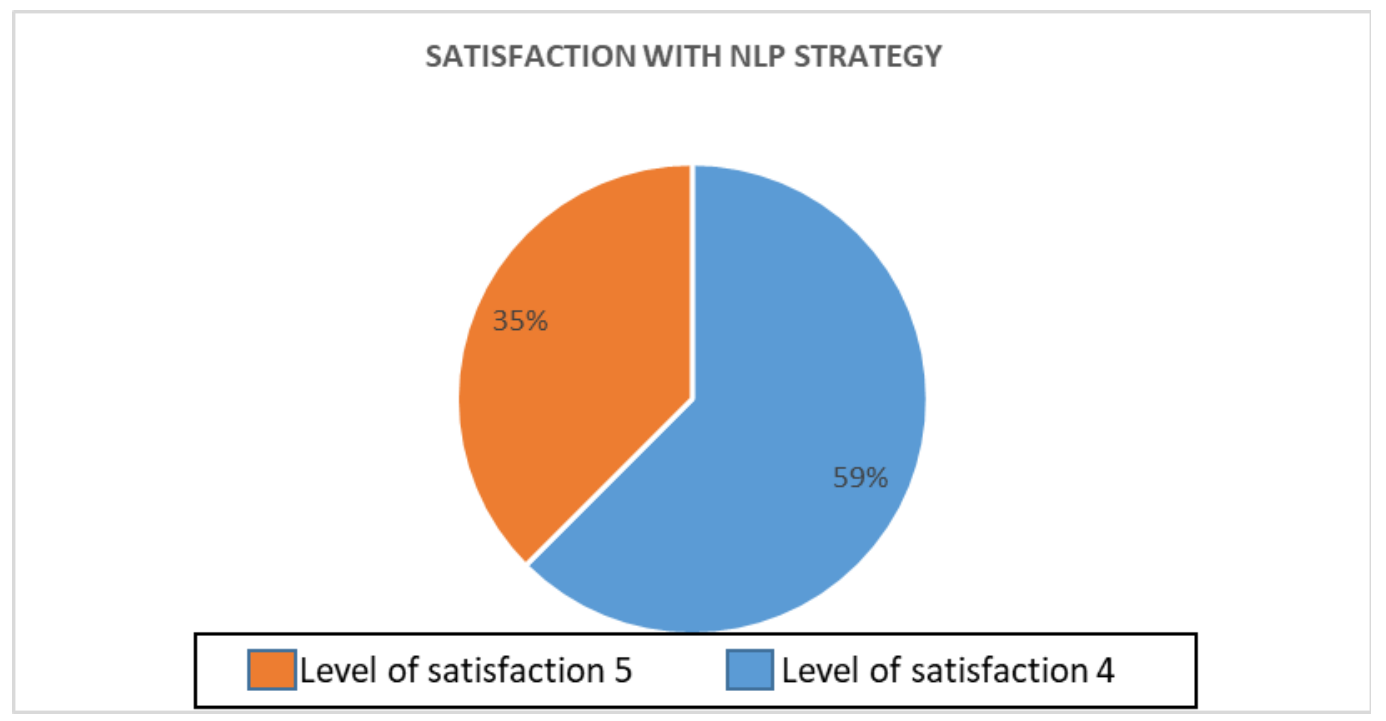

Figure 5. Students' satisfaction with the strategy

The teacher kept a log with his observations of what happened in the classes after the intervention.

His perception confirmed that students pronounced the verbs accurately after the instruction. He says:

On this day, I implemented the activity for the teaching of the pronunciation of regular verbs. In general, nobody made mistakes in terms of the pronunciation of regular verbs present in the text about phony doctor. This includes both high-achievers and low-achievers. However, the recording will say if my perception in class is correct. (Teacher's entry March 12, 2015)

After this, the teacher reported repeated success in students' pronunciation of the verb ending during classroom interaction.

A high-achiever pronounced the verb look in the past correctly. In terms of uptake, he repeated the pronunciation several times while he was smiling, looking at me, as if he were telling me he remembered the class when we worked on the pronunciation of regular verbs. (Teacher's entry, March 24, 2015).

He reported accurate spontaneous pronunciations of called, experienced, shared (Entry April 13, 2015), as well as of finished, tired, enjoyed (Teachers' entry, April 15, 2015). Only two mispronounced verbs were reported in the log: tired (April 15) and looked (April 16).

The teacher's observation reinforces the statistical data; students seem to have increased the pronunciation accuracy of these verbs after explicit pronunciation instruction using NLP techniques.

\section{Discussion}

The difficulty of teaching English pronunciation has been reported by authors like Pourhossein,(2011b) who asserts that "...there is a burning need for an increase in the amount of serious research at all levels into a wide range of issues to do with ESL pronunciation teaching" (p. 81). Bearing in mind how generalized is the problem with the pronunciation of regular verbs in the past as found in the literature review, and that learners whose mother tongues are romance languages, including Spanish, are not the exception to such a problem, a study like this might help teachers find solutions in their classrooms through NLP (Dilts \& Epstein's, 1995; James, 1996; Dilts \& Epstein, 1997; Bashir \& Ghanni, 2012). NLP has been explored in some fields of education with great success. In the current study, the aim was to assess how useful it was for a generalized pronunciation issue among Spanish speakers such as past tense ending of regular verbs.

Compared to similar studies, the present one showed positive results, giving NLP great relevance to be explored by researchers interested in the field of pronunciation teaching. Like in the study by Delatorre and Baptista (2014), in our study there was a paragraph reading task and a free speech task. The findings are, however, different. In Delatorre and Baptista's work, in the reading task, accuracy decreased apparently because of orthographic influence resulting in more frequent epenthesis production; in our study, the percentage of accuracy in the reading task was higher in both implementations. In the free speech task, Delatorre and Baptista's results showed higher accuracy: in our study, accuracy decreased in general, but remained higher in the NLP group. 
In general, the NLP group outperformed the standard group in both implementations. In implementation two, the accuracy in activity one was higher than in activity two; this might have happened given the nature of the activities since the first one was more controlled and the second one was more natural. The performance of the NLP group increased in the second activity. A more detailed look at the groups of verbs in terms of the final sound, showed the only group of verbs in which the Standard group outperformed the NLP group was the /id/ group in Activity two, with a difference of $21 \%$. In the rest, the performance of the NLP group was higher. Actually, the difference in terms of $/ \mathrm{t} /$ and $/ \mathrm{d} /$ groups is higher in Activity two. For instance, the difference for the /t/ group in Activity one was 14\%; in terms of the /d/ group was 39\%. In Activity two, the difference for the /t/ group was $29 \%$, while for the /d/ group was $43 \%$.

\section{Conclusions}

The pronunciation of regular verbs in the past is troublesome for Spanish speakers (Alves, 2004; Baptista, 2001, 2002; Delatorre, 2006a; Fernandes, 2009; Gomes, 2009, 2010; Pereira, 1994; Roothooft, 2013). However, the use of an intentional pronunciation instruction strategy reduced this frequent pronunciation error (Delatorre \& Baptista, 2014; Sato, 2012). The intervention proved to be beneficial for the students involved since their recalling of thecorrect pronunciation of the verbs was better in both implementations. In the first implementation their progress is represented in a $30 \%$ increase compared to the standard group whose progress is represented in a $10 \%$ increase. The second implementation seeking to see the effect of NLP instruction in more natural performance was again beneficial since the NLP group had again higher accuracy: $70,4 \%$ versus $45,8 \%$ in the standard group. NLP seems to be an effective teaching strategy that EFL teachers could incorporate into their pronunciation teaching repertoire.

The use of NLP as an instruction tool for pronunciation had a positive impact on students' motivation as reported in the satisfaction survey in which they all agreed that the strategy was interesting and fun which was corroborated in the teacher's insights about classroom interaction, students' engagement in the activity and by the good results obtained overall.

NLP could be part of teachers' instructional repertoire for the intentional teaching of pronunciation of troublesome issues such as the -ed endings of regular past tense, but also for other pronunciation practices in any classroom and context.

This study is a contribution to the scholarly of teaching and learning, conducted by teachers to understand their practice better and to contribute to others professional development. There are limitations to this study, though. The number of participants, the reading text, the depth of analysis in the nature of students' errors. Therefore, further research on this issue should consider:

1) A larger number of students that makes the sample more statistically representative.

2) The use of other NLP techniques.

3) A reading text that contains an even number of verbs from the three different -ed past tense endings.

4) A deeper analysis of students' specific errors students.

\section{Acknowledgments}

We thank CEDU (Center for Teaching Excellence Uninorte) at Universidad del Norte, Barranquilla, Colombia for their support to develop this study within their pedagogical laboratory strategy.

\section{References}

Alves, U. K. O (2004). Papel da instrução na aquisição fonológica do inglês como L2: evidências fornecidas pela teoria da otimidade. 335f ( Dissertação Mestrado em Letras). Programa de Pós-Graduação em Letras, Universidade Católica de Pelotas, Pelotas.

Añorga, A., \& Benander, R. (2015). Creating a Pronunciation Profile of First-Year Spanish Students. Foreign Language Annals, 48, 434-446. https://doi.org/10.1111/flan.12151

Avery, P., \& Ehrlich, S. (2006). Teaching American English Pronunciation. Oxford University Press.

Baker, A. (2002). Introducing English Pronunciation, a Teacher's Guide to Tree or Three? And Ship or Sheep? Cambridge: Cambridge University Press.

Baptista, B. O. (2001). Frequent pronunciation errors of Brazilian learners of English. In M. B. M. Fortkamp, R. P. Xavier (Orgs.) EFL teaching and learning in Brazil: theory and practice (p. 223-230). Florianópolis: Insular. 
Baptista, B. O. (2002). Languages in contact: Brazilian English interlanguage phonology. In congresso internacional das linugagens, I, 2002, Erechim. Apresentação Oral. Erechim: URI

Bashir, A., \& Ghanni, M. (2012). Effective Communication and Neurolinguistic Programming. Pak. J. Commer. Soc. Sci., 6(1), 216-222

Brewer, C. (1995). Music and Learning: Integrating Music in the Classroom. New Horizons for Learning Journal, X(1).

Burgess, J., \& Spencer, S. (2000). Phonology and pronunciation in integrated language teaching and teacher education. System, 28(2), 191-215. https://doi.org/10.1016/S0346-251X(00)00007-5

Buss, L. (2013). Pronunciation from the perspective of pre-service EFL teachers: An analysis of internship reports.In J. Levis, \& K. LeVelle (Eds.), Proceedings of the 4th Pronunciation in Second Language Learning and Teaching Conference (pp. 255-264). Ames, IA: Iowa State University.

Caballero, D. (2012). Analysis of techniques used by native and non-native English-speaking teachers when treating oral errors in tasks at Instituto de Idiomas, Universidad del Norte (Unpublished Master's thesis). Universidad del Norte, Barranquilla (Colombia).

Calderon, K., Rios , J., \& Toro, L. ( 2016). The state of the art of pronunciation teaching in pre-service practices of the English language teaching program (Unpublished thesis). Universidad Tecnológica de Pereira, Pereira (Colombia).

Carrión, S. (2007). Programación Neurolingüistica. Intermedio Editores Ltda.

Celce-Murcia, M., Brinton, D., \& Goodwin, J. (2010). Teaching pronunciation. A reference for teachers of English to speakers of other languages (2nd ed). Cambridge, UK: Cambridge University Press.

Dalton, C., \& Seidlhofer, C. (1995). Pronunciation. Oxford: Oxford University Press.

Darn, S. (2005). Teaching English. Retrieved August 6, 2011, from http://www.teachingenglish.org.uk/articles/neuro-linguistic-programming-elt

Delatorre, F. (2006). Brazilian EFL learners' production of vowel epenthesis in words ending in -ed. $214 \mathrm{f}$. (Dissertação Mestrado em Letras/Inglês e Literatura Correspondente). Programa de Pós-Graduação em Letras/Inglês e Literatura Correspondente, Universidade Federal de Santa Catarina, Florianópolis.

Delatorre, F., \& Baptista, B.O. (2014). The Effect of Long-Term Instruction on a Brazilian.

Learner's Production of English Verbs Ending in -ed. Revista, X(1), 58-79.

Dickerson, W. B. (1994). Empowering students with predictive skills. In J. Morley (Ed.), Pronunciation pedagogy and theory: New views, new directions (pp. 17-33). Alexandria, VA: TESOL Publications

Dilts, R., \& Epstein, T. (1997). Aprendizaje Dinámico con PNL. Barcelona: Ediciones Urano S.A.

Dilts, R,. \& Epstein, T. (1995). Dynamic Learning. Capitola, CA: Meta Publications.

Fernandes, R. K. M. (2009). Inteligibilidade e inglês como língua internacional: um estudo de caso de palavras em -ed produzidas por falantes brasileiros. 113f. (Dissertação Mestrado em Estudos Ingleses e Americanos). Faculdade de Letras, Departamento de Estudos Linguísticos, Universidade de Lisboa: Lisboa.

Foote, J., Holtby, A., \& Derwing, T. (2011). Survey of the teaching of pronunciation in adult ESL programs in Canada, 2010. TESL Canada Journal, 29(1), 1-22. https://doi.org/10.18806/tesl.v29i1.1086

Fraser, H. (2000). Literacy vs oral communication skills for ESL learners. In Literacy Link, Newsletter of the Australian Council for Adult Literacy.

Gomes, M. L. C. (2009). The production of words with the morpheme ED by Brazilian speakers of English as a foreign language. In: international symposium on the acquisition of second language speech, 5th, 2008, Florianópolis. Proceedings of the Fifth International Symposium on the Acquisition of Second Language Speech. Florianópolis: UFSC, pp. 222-235.

Gomes, M. L. C. (2010). The pronunciation of ed morpheme by Brazilians: from a discrete to a gradient view. In A. S. Rauber, M. A. Watkins, R. Silveira, \& R. D. Koerich, (Orgs.) The acquisition of second language speech: Studies in honor of professor Barbara O. Baptista (pp. 221-242). Florianópolis: Insular.

Gomez, D., \& Pelaez, J. (2012). Promotion and teaching of pronunciation in a ninth grade of a public school in Pereira Risaralda (Unpublished thesis). Universidad Tecnologica de Pereira, Pereira (Colombia).

Gutiérrez Gutiérrez, D. (2005). Developing Oral Skills through Communicative and Interactive Tasks. Profile: 
Issues in Teachers' Professional Development, 6(1), 83-96.

Henderson, A., Curnick, L., Frost, D., Kautzsch, A., Kirkova-Naskova, A., Levey, D., ... Waniek-Klimczak, E. (2015). The English Pronunciation Teaching in Europe Survey: Factors Inside and Outside the Classroom. In J. Mompean, \& J. Fouz-González (Eds.), In Investigating English Pronunciation: Current Trends and Directions (pp. 260-291). Palgrave Macmillan. https://doi.org/10.1057/9781137509437_12

Lin, Fan, \& Chen ( nd). Teaching Pronunciation in the Learner-Centered Classroom. National Kaohsiung First University of Science and Technology: Taiwan. Retrieved from http://www2.nkfust.edu.tw/ emchen/Pron/papers/paper-1.html

Londoño-Diaz, Mario. A.(2014). Scaffolding students' phonological competence through the integration of pronunciation learning strategies (Unpublished thesis). Universidad Tecnológica de Pereira, Pereira (Colombia).

Mariano, M. H. (2009). The influence of training and instruction on the production of words ending in -ed by Brazilian EFL learners. 89f. (Dissertação Mestrado em Letras/Inglês e Literatura Correspondente). Programa de Pós-Graduação em Letras/Inglês e Literatura Correspondente, Universidade Federal de Santa Catarina, Florianópolis.

Morin, R. (2007). A neglected aspect of the standards: Preparing foreign language Spanish teachers to teach pronunciation. Foreign Language Annals, 40, 342-360. https://doi.org/10.1111/j.1944-9720.2007.tb03206.x

Muñoz, A., \& Aristizábal L. (2002). Assessing Spoken Language in EFL: Beliefs and Practices. Revista Universidad EAFIT, 129, 63-74.

Pereira, C. M. (1994). Acquisition of morphological rules by EFL Brazilian students (Dissertação (Mestrado em Letras/Inglês e Literatura Correspondente). Programa de Pós-Graduação em Letras/Inglês e Literatura Correspondente, Universidade Federal de Santa Catarina, Florianópolis.

Pourhossein, A. (2011a). A Study on the Situation of Pronunciation Instruction In ESL/EFL Classrooms. Journal of Studies in Education, 1(1), E4. https://doi.org/10.5296/jse.v1i1.924

Pourhossein, A. (2011b). Why is pronunciation so difficult to learn? English Language Teaching, 4(6). .

Roberto Rengifo, A. (2009). Improving Pronunciation through the Use of Karaoke in an Adult English Class. Profile: Issues in Teachers' Professional Development, 11(1), 91-105.

Roothooft, H. (2017). Developing a methodology for researching the effects of corrective feedback on the acquisition of the past tense: a pilot study. ELIA: Estudios De Lingüistica Inglesa Aplicada, [s.l.], 12, 211-242,

Saito, K. (2012). Effects of instruction on L2 pronunciation development: A synthesis of 15 quasi-experimental intervention studies. TESOL Quarterly, 46, 842-854. https://doi.org/10.1002/tesq.67

Sifakis, N., \& Sougari, A. (2005). Pronunciation issues and EIL pedagogy in the periphery: A survey of Greek state school teachers' beliefs. TESOL Quarterly, 39(3), 467-488. https://doi.org/10.2307/3588490

Silveira, R., \& Alves, U. K. (2006). Noticing e instrução e explícita: Dados empíricos da aprendizagem fonético-fonológica. In: Encontro Nacional sobre Aquisição da Linguagem, 7. Porto Alegre. Apresentação Oral. Porto Alegre: PUC/RS.

Sumrall, S. (s.f.). Advanced Behavioral Consultants. Retrieved on August 7, 2011, from http://www.healthsurvey.com/nlpeducation.htm.

Takashima, H., \& Ellis, R. (1999). Output enhancement and acquisition of the past tense. In R. Ellis (Ed.), Learning a Second Language through Interaction (pp. 173-188) Amsterdam/Philadelphia: John Benjamins Publishing Company. https://doi.org/10.1075/sibil.17.12tak

Wei, M. (2006). A literature review on strategies for teaching pronunciation. ERIC Document Reproduction Service No. ED 4. 


\section{Appendices}

\section{Appendix A. Reading text implementation 1}

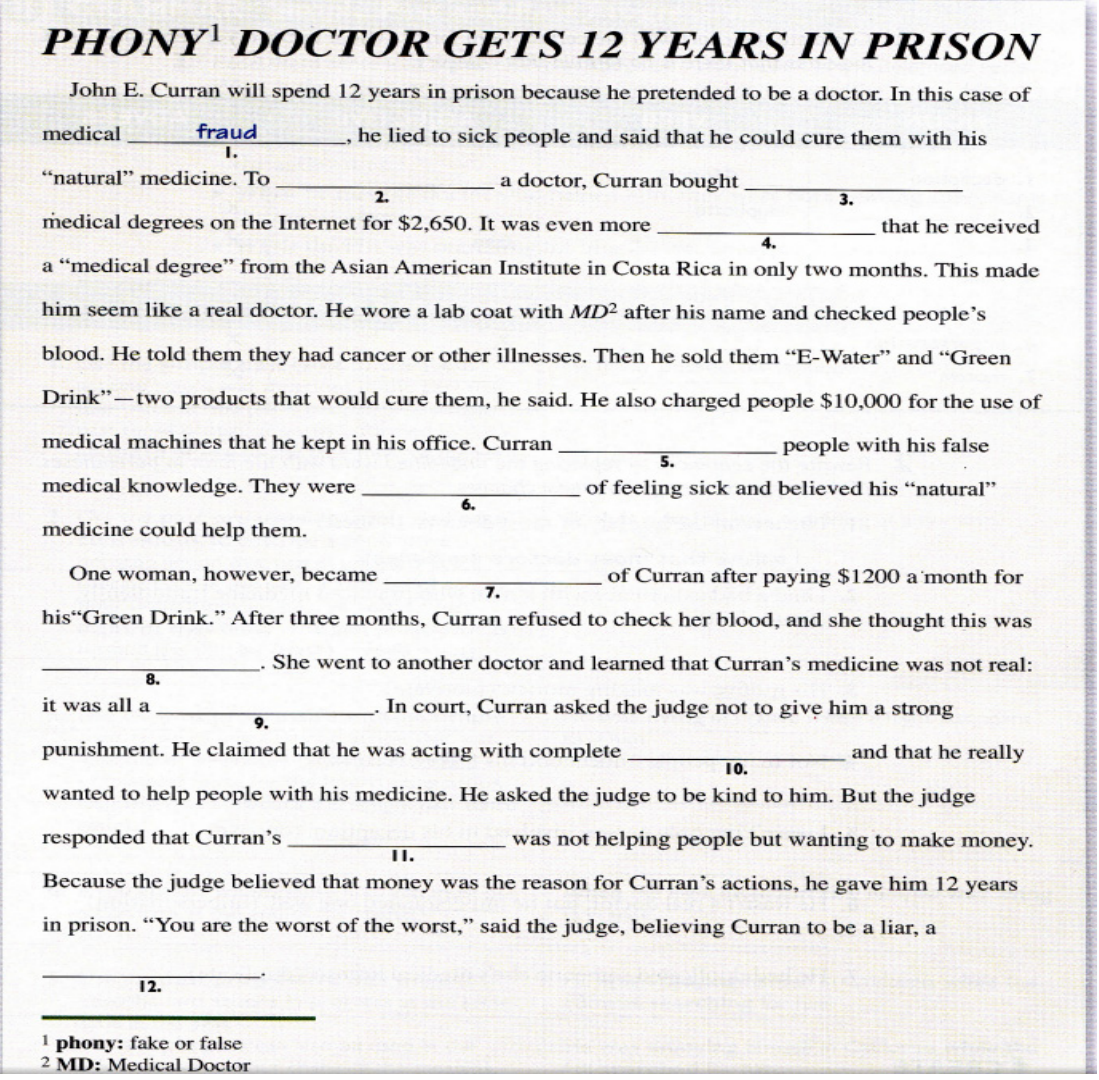

\section{Appendix B: Reading text implementation 2:}

Read out loud the excerpts from students' essays in the United States to enter college and record your voice. Don't worry if you make mistakes.

\section{A person I admire}

My mother walks with crutches and has scars all over her legs. When she was a young girl, she was walking past a building site when a piece of machinery fell on her and mangled her legs. The doctors thought she would never walk again. However, she believed that life still had a lot of opportunities in store for her, and she was right. Now she has four children, volunteers at the library, and has become a teacher.

\section{An experience that changed my life}

I spent last summer volunteering in a village in the Andes. The landscape was so beautiful. Birds soared above us. However, 1 discovered that 1 was afraid of heights. I was so scared that 1 actually collapsed once. I worked hard to face my fears, though, and while I'm still nervous, I know how to control myself. In short, 1 learned a lot about my mental limitations and how to meet those challenges.

\section{Appendix C: Instruction for free speech implementation 2}

Read the following questions. Choose ONLY ONE. Take some minutes to organize your ideas. Then, record your answer including as many of the verbs and/or expressions in the box below as possible.

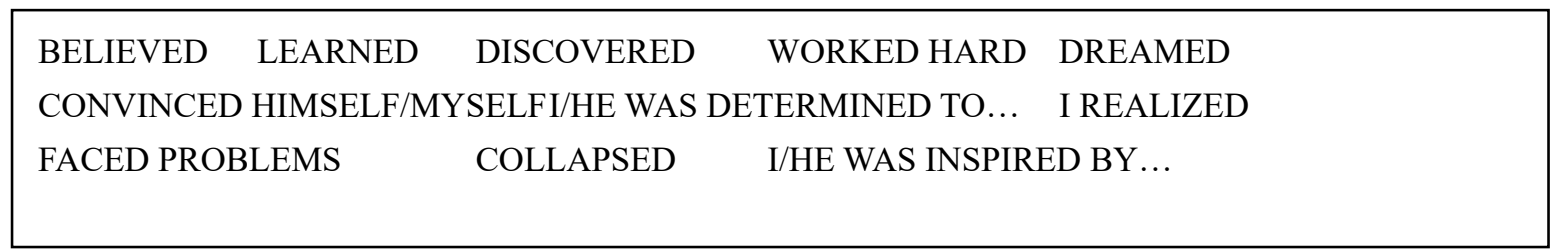


1. What was an obstacle that you overcame in life? What kind of obstacle was it? What did you do to overcome it? Why was it difficult to overcome?

2. What do you think was the key for Richard Van Ornum to overcome his physical problem? What was the factor that helped him the most to succeed in life?

\section{Appendix D: Satisfaction survey}

The following survey is applied with the aim of knowing your impressions about the activity implemented by Professor DAVID RICARDO CABALLERO DE LA HOZ in the English class to teach the correct pronunciation of the REGULAR VERBS in the past in the framework of the study that is being carried out in LEVEL III to improve the teaching of pronunciation at that level. Please read each of the questions carefully and answer as honestly and objectively as possible.

1. On a scale of 1 to 5 , indicate your level of satisfaction with the activity to learn the pronunciation of regular verbs.

1. Completely satisfied

2. Satisfied

3. Neither satisfied nor dissatisfied.

4. Unsatisfied

5. Totally dissatisfied

2. Did this activity help you learn better pronunciation of verbs?

1. Very much so

2. All right. All right.

3. Undecided

4. I disagree

5. Strongly disagree

3. Write a sentence that describes your level of satisfaction with the activity.

4. Compared to other pronunciation activities you have experienced in previous classes, the verb pronunciation activity is:

1. More effective

2. Equally effective

3. Less effective

5. Do you think you will remember the correct pronunciation of verbs?

1. Always

2. Most of the time

3. Many times

4. Very rarely

5. Never

6. Indicate the degree of difficulty of a musical component in the activity (e.g. use of clapping, rhythm in pronunciation, etc.)

1. Quite easy

2. Easy

3. Neither easy nor difficult

4. Difficult

5. Quite difficult

7. Would you like to see more activities of this kind implemented?

Yes No 
8. What suggestions or recommendations would you make to the teacher to improve the design of the activity?

\section{Appendix E.}

List of regular verbs.

\begin{tabular}{|c|c|c|}
\hline Bert /t/ & Fred $/ \mathbf{d} /$ & David /Id/ \\
\hline 1. Ad vanced & 1. An swered & 1. Com ple ted \\
\hline 2. Cooked & 2. A rrived & 2. Cons truc ted \\
\hline 3. De ve loped & 3. Burned & 3. Cre a ted \\
\hline 4. Es ta blished & 4. Called & 4. De ci ded \\
\hline 5. Fixed & 5. En joyed & 5. De di ca ted \\
\hline 6. Liked & 6. Ha ppened & 6. Es ti ma ted \\
\hline 7. Looked & 7. Learned & 7. In teres ted \\
\hline 8. Marked & 8. Loved & 8. In ven ted \\
\hline 9. Stopped & 9. Or dered & 9. In vi ted \\
\hline 10. Walked & 10. Planned & 10. Poin ted \\
\hline 11. Washed & 11. Played & 11. Star ted \\
\hline 12. Watched & 12. Showed & 12. Wan ted \\
\hline 13. Worked & 13. Stu died & 13. Was ted \\
\hline
\end{tabular}

\section{Copyrights}

Copyright for this article is retained by the author(s), with first publication rights granted to the journal.

This is an open-access article distributed under the terms and conditions of the Creative Commons Attribution license (http://creativecommons.org/licenses/by/4.0/). 